\title{
Diversity patterns and palaeoecology of benthic communities of the Kanosh Formation (Pogonip Group, Utah, western USA)
}

\author{
Richard Hofmann ${ }^{1}$ (D) Jan Philipp Kehl ${ }^{1}$
}

Received: 23 September 2019 / Revised: 6 January 2020 / Accepted: 26 March 2020 / Published online: 28 June 2020

(C) The Author(s) 2020

\begin{abstract}
The Dapingian to Darriwilian Kanosh Formation is one of the most fossiliferous units of the Pogonip Group (Great Basin, western US). It records a critical phase of the so-called Great Ordovician Biodiversification Event (GOBE) during which many marine clades diversified on lower systematic levels. However, a comprehensive palaeoecological analysis has not been presented for this unit so far. Based on newly collected material from three sections in the type area at Ibex, we reconstruct benthic marine communities, analyse diversity patterns, and discuss its significance for the GOBE. We find no differences in species' composition across the formation with respect to brachiopods. Benthic assemblages are dominated by Shoshonorthis michaelis, alongside the presence of Anomalorthis lonensis and Anomalorthis utahensis across the whole unit. Trilobites show a more pronounced facies restriction with species of Kanoshia and Pseudomera being observed in more proximal limestone whereas Bathyurellus and Pseudoolenoides occur in fine-grained, low-energy deposits. The skeletal limestone also records abundant bioclasts of bryozoans, echinoderms, and receptaculitids, suggesting an ecologically diverse and tiered community being present in the inner shelf zone. However, most of these groups are not particularly diverse in terms of species richness. This implies that principle establishment of typical members of the "Palaeozoic Fauna" is not associated with a local diversification of clades. The comparably low habitat diversity of the Kanosh Fauna likely reflects environmental constraints such as high rates of siliclastic input. Additionally, these mainly Dapingian communities still represent a base-line fauna before the principal diversification took place.
\end{abstract}

Keywords Palaeoecology $\cdot$ Middle Ordovician $\cdot$ Diversification $\cdot$ Benthos

\section{Introduction}

Strata of the Pogonip Group of western Utah, and eastern and central Nevada have long been acknowledged to represent an exquisite archive of Lower and Middle Ordovician marine life in western Laurentia (Hintze and Davis 2003). As one of the most fossiliferous and lithologically conspicuous units of the Pogonip Group, the Kanosh Formation received considerable attention expressed in studies on stratigraphy (Hintze 1953;

Electronic supplementary material The online version of this article (https://doi.org/10.1007/s12549-020-00426-3) contains supplementary material, which is available to authorized users.

Richard Hofmann

richard.hofmann@mfn.berlin; fossilrich@gmail.com

1 Leibniz Institute for Evolution and Biodiversity Science, Museum für Naturkunde, Invalidenstr 43, 10115 Berlin, Germany
Hintze 1973; Fortey and Droser 1996; Adrain et al. 2012), palaeoecology and taphonomy (Wilson et al. 1992; Li and Droser 1999; Boyer and Droser 2003), and systematic palaeontology of various fossil groups including trilobites (Hintze 1953; Adrain et al. 2012), brachiopods (Ulrich and Cooper 1938; Jensen 1967), bryozoans (Ernst et al. 2007), echinoderms (Sumrall and Sprinkle 2015), and palynomorphs (Vecoli et al. 2015). Despite these efforts, no prior palaeoecological analysis exists that examined major macroinvertebrate groups together (few samples of the Kanosh are presented by Finnegan and Droser (2005) though). In this study, we examine biodiversity and palaeoecological patterns across the Kanosh Formation based on a quantitative palaeoecological analysis. We furthermore explore these patterns with respect on the Great Ordovician Biodiversification Event (GOBE). The GOBE is held as one of the most distinctive periods of diversification on lower taxonomic levels (i.e. genus and family level). It marks the initial radiation of the "Palaeozoic evolutionary fauna" (Sepkoski 1981). Several 
benthic groups exhibit pulses in diversification roughly across the Lower to Middle Ordovician transition (Rasmussen et al. 2007; Servais et al. 2010). Additionally, differences in the timing and phylogenetic patterning (Westrop and Adrain 1998; Harper et al. 2015; Colmenar and Rasmussen 2018; Franeck and Liow 2019; Stigall et al. 2019) result in seemingly divergent local representations of the event. However, there appears to be emerging consensus that the main pulse of the GOBE occurred over a rather confined time interval: the Darriwilian (Rasmussen et al. 2019; Stigall et al. 2019). The Kanosh Formation is mainly of Dapingian (early Middle Ordovician) Age. It thus records the transition from the PreGOBE to the Main GOBE phase sensu Stigall et al. (2019). Accordingly, analyses of ecological and diversity patterns are important to elucidate underlying controls of the GOBE as well as adding to appreciation of local differences.

\section{Geological setting and stratigraphy}

In the study area (Fig. 1), the Kanosh Formation (or Kanosh Shale) is a succession of shale, siltstone, and mostly bioclastic packstone, wackestone, and grainstone (see also Figs. S1-S3). Together with the overlying Lehman Formation, it represents the youngest portion of the Pogonip Group of central Utah and central and eastern Nevada, and records the last major marine incursion during the Middle Ordovician (Hintze 1973). As a whole, the Pogonip Group largely represents a carbonate ramp system at the western margin (Dattilo 1993; Hintze and Davis 2003; Miller et al. 2012) of central Laurentia and was situated between 0 and 30 degrees south at the time of deposition (Fig. 2). The Kanosh Formation reaches an approximate thickness of $170 \mathrm{~m}$ in the type area (Hintze 1973) at Ibex (western Utah). Hintze (1973) subdivided it into five informal members: lower olive shale and calcarenite member, silty limestone member, upper olive shale and calcarenite member, sandstone and shale member, and calcisiltite member (Fig. 3). Equivalent strata in eastern Nevada (e.g. the Egan Range) are of similar thickness (Ross (1970) and personal observation). The Kanosh Formation pinches out towards the northwest where the Tooele Arch supposedly formed a subaerial area or at least shoals (Ross 1970) during the Middle Ordovician (Fig. 3). It is noted here that the general idea of an arch manifested in the architecture of Lower Palaezoic sedimentary succession of the western US has been criticised (Myrow et al. 2003). However, it is beyond the scope of our contribution to clarify this issue with the data at hand.

The underlying Juab Formation is generally interpreted as a gently inclined carbonate ramp without a noticeable relief (Miller et al. 2012). The Kanosh appears to rest conformably on the Juab Formation and marks a transgression with the widespread deposition of shelf muds and siltstone indicative of quiet water conditions. Ross et al. (1989) suggested that the

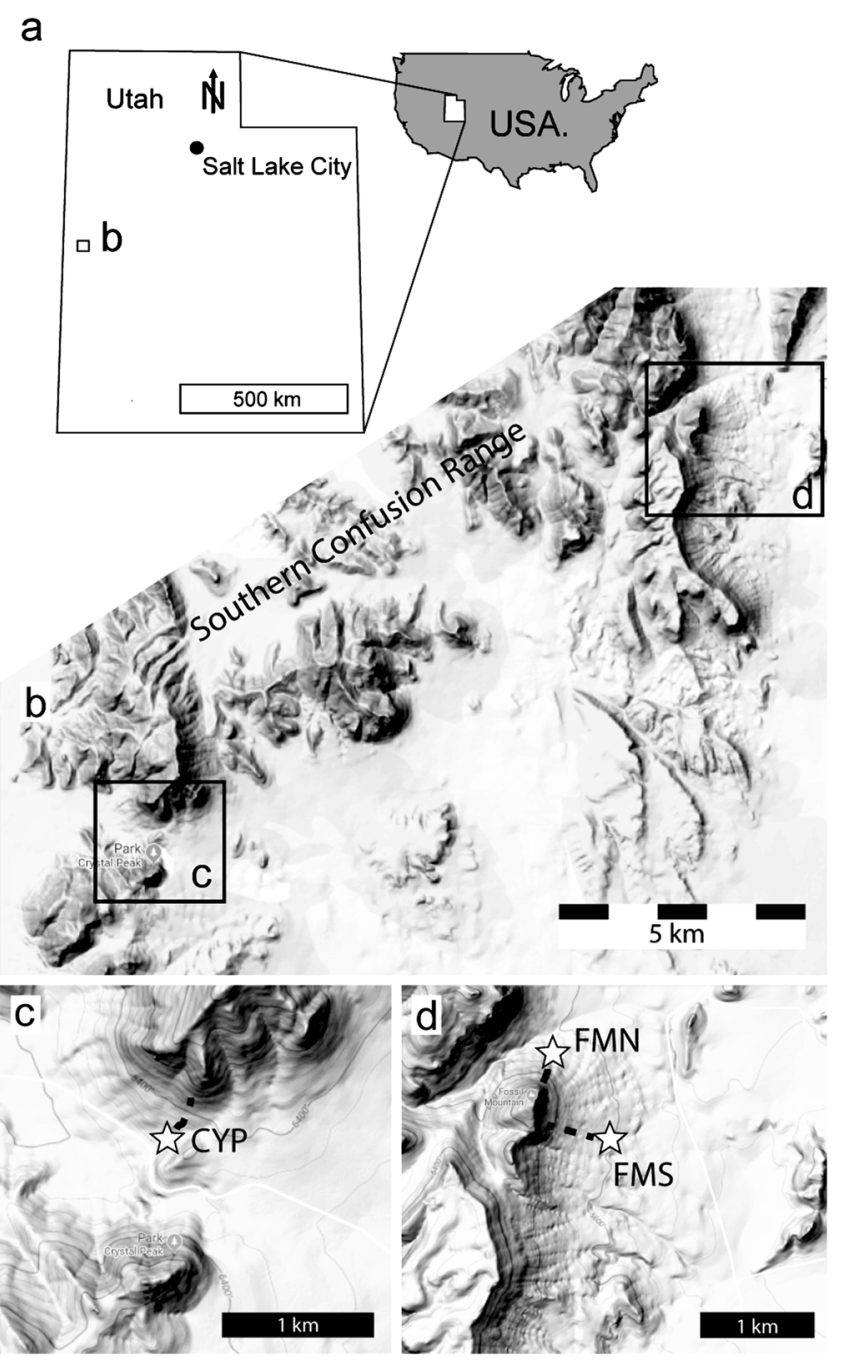

Fig. 1 a Map of Utah showing the localities in (b) the southern Confusion Range at (c) Crystal Peak and (d) Fossil Mountain. CYP, Crystal Peak; FMN, Fossil Mountain North; FMS, Fossil Mountain South. Exact GPS coordinates provided in the supplement. Terrain maps of $\mathbf{b}-\mathbf{d}$ provided by Google Maps

Kanosh Basin was protected from major storm activity by oolite shoals situated to the west. It is thus likely that it rather mimics deep-water conditions instead of being necessarily deep in terms of absolute water depth. The general facies architecture with the recurrent and abrupt intercalations of thin- to thick-bedded bioclastic grain- and rudstone (Fig. S4) lends support to the principal interpretation that the Kanosh system was not a deep intrashelf-trough but a protected and relatively shallow embayment of considerable extent (some $100 \mathrm{~km}$ ). Several metre-thick packages of skeletal limestone in the middle part of the Formation suggest that the area was affected by storm waves at certain times (Boyer and Droser 2003), probably during shoreline progradation. The overlying Lehman Formation has been interpreted (e.g. Boyer and Droser 2003) as a restricted lagoon and intertidal mudflat, which is confirmed by own observations. The Watson 
Fig. 2 a Global palaeogeographical reconstruction of the Darriwilian (460 Ma) after Blakey (2019). La, Laurentia; Si, Siberia; Ba, Baltica. b Palaeogeography of western Laurentia during the Middle Ordovician showing the study locality. NV, Nevada; UT, Utah
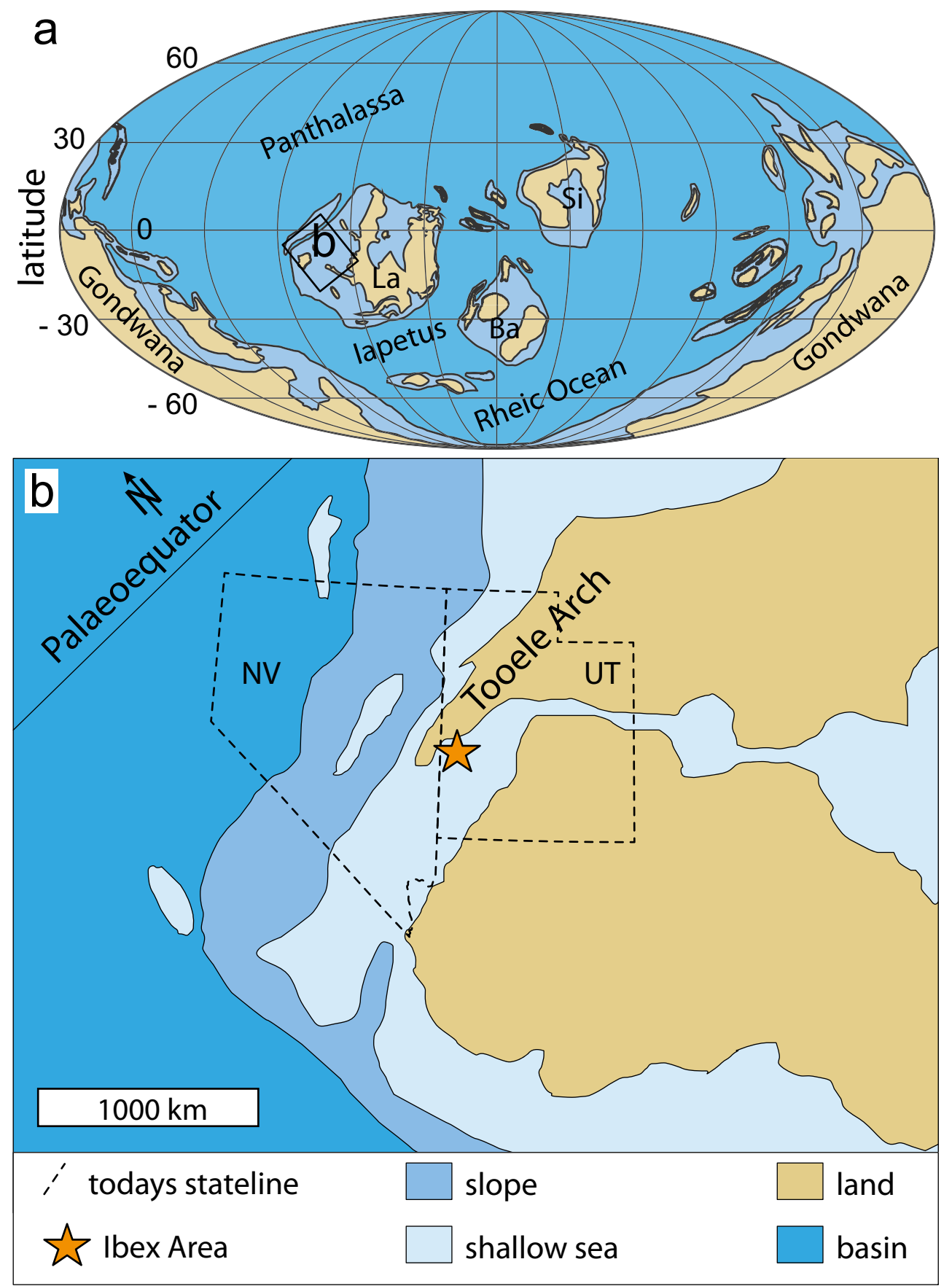

Ranch Quartzite Formation represents deposits of a tidally influenced sandy shoreline (Hintze and Davis 2003; Miller et al. 2012). Figure 3 shows a general facies interpretation and reconstructed sea level curve for the Kanosh succession.

Stratigraphic age control is provided by the occurrence of trilobites noted herein and described and established by others (Hintze 1953; Adrain et al. 2012). One of the most characteristic trilobites of Zone M, Kanoshia kanoshensis is not observed above the sandstone and shale member, which supports previous placements of the Zone $\mathrm{M}$ - Zone $\mathrm{N}$ transition within this member (Adrain et al. 2012; Edwards and Saltzman 2014; Vecoli et al. 2015). This agrees with the statement of Hintze (1973) that zone M extends "from the base of the Kanosh to about 300 feet" (91.4 m) of the formation. Adrain et al. (2012) indicated that the Zone $\mathrm{M}$ - Zone $\mathrm{N}$ transition marks the Dapingian-Darriwilian boundary in the Ibex area as supported by isotopic data (Edwards and Saltzman 2014).

Taken together, the Kanosh Formation represents the upper part of the Dapingian and the lower part of Darriwilian. 


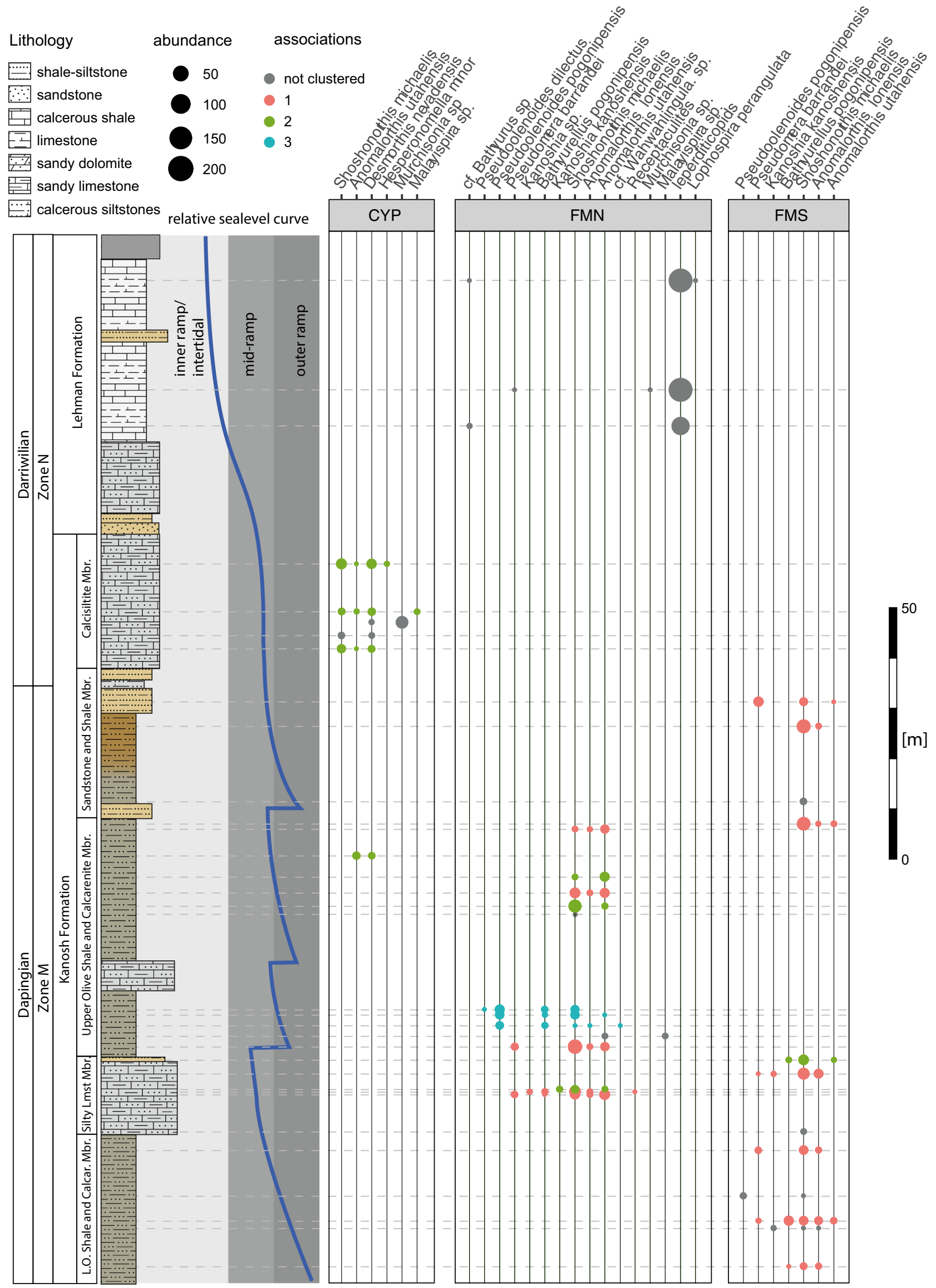


Fig. 3 Composite section of the Kanosh and the Lehman Formations showing approximate sampled levels of in each section (CYP, Crystal Peak; FMN, Fossil Mountain North; FMS, Fossil Mountain South). Exact sampled horizons shown in logged section in the supplement

\section{Locality and methods}

The analysis employs absolute abundance data from samples of the Kanosh Formation (and to a lesser extent the Lehman Formation) from western Utah. Field collections and bed-bybed logging of the strata (see supplement Figs. S1-S3) has been carried out in the classical sections of Hintze (1973) at Fossil Mountain and Crystal Peak in the Ibex area (Fig. 1) during a field session in August and September 2016. Identification of the sedimentological facies is based on field observations including grain size, bedding, lithology, and stacking patterns. A general facies interpretation with respect to relative sea level is provided in Fig. 3. Principal sedimentary facies are shown in Fig. S4. The sections FMS and FMN are situated close together at the Fossil Mountain locality. CYP (Crystal Peak) is $16 \mathrm{~km}$ southwest of Fossil Mountain, which is somewhat more distal causing some variation in the facies development. Nevertheless, the informal member subdivision is well recognisable. We do note however that the composite section and respective sample levels shown in Fig. 3 retain the stratigraphic positions of the collections with respect to facies and members and not necessarily absolute meters. The exact sample positions are shown in the stratigraphic logs provided in the supplement (Figs. S1-S3).

Sampling was undertaken in fossiliferous beds of generally bioclastic silty limestones mostly packstone and to a lesser extent wackestone and grainstone. The sampling routine was based on hammer-aided disintegration of rock and immediate examination of promising fossil content. Sampling was preferably carried out until at least 30 specimens could have found or until new collecting did not result in finding of new taxa. Beds showing evidence of strong reworking, as for instance size-sorting, gradation or abundant abrasion of fossils, were not included in the quantitative analysis. If necessary, standard macroinvertebrate preparation techniques were performed to reveal morphologic details enabling robust taxonomic determination. Fossils were coated with ammonium chloride before being photographed in the photolab of the Museum für Naturkunde Berlin with a macroscopic SLR camera. Stacked shooting was executed with Helicon Focus.

Fossils were identified to the species level relying on up-todate taxonomic surveys (Table 1). Recognised taxa include brachiopods (Fig. 4), trilobites (Fig. 5), and gastropods (Fig. 6). The latter were mostly included from weathered float if stratigraphic level could be confidentially restored, or observed as monospecific assemblages on slabs. Although we tried to identify them, gastropods are no integral part of the benthic associations.
Echinoderms, bryozoans, and leperditicopids were abundantly observed in the field and on collected slabs but not included because they cannot be reasonably quantified in terms of specimen abundance. Evidence for autochthonous and paraautochthonous communities is provided by the fact that most brachiopods are present as complete specimens, sometimes preserved in life position or in nested clusters. Trilobite carapaces and exuviae are much more susceptible for post-mortem displacement even if transported on very short distances. Thus, the presence of fairly intact cephalons, cranidiums, and pygidia was taken as sufficient evidence for them to be part of a (para-)autochthonous community.

Fossil occurrences were counted using the MNI (minimum number of individuals) method as discussed by Gilinsky and Bennington (1994) and then tabulated for each sampled horizon (excel-sheet "kanosh.csv", supplement). We identified 831 specimens (excluding estimated 500 specimens of leperditicopids) of which 650 are brachiopods and 137 are trilobites. A set of multivariate analyses was performed using the $R$-package vegan (Oksanen et al. 2019) on the faunal abundance data including all samples with more than 10 specimens. Cluster analysis (unweighted paired-group method, Raup index of similarity) and non-metric multidimensional scaling (NMDS) were used to recognise and confirm recurrent sets of taxa, which are established methods to distil palaeocommunities from occurrence data (e.g. Fürsich et al. 1995; Hofmann et al. 2013; Foster et al. 2017). The NMDS method is particularly useful for reconstructing (palaeo)ecological communities. By using ranked orders instead of absolute distances among samples, it minimises ordination-artefacts in noisy or incomplete data such as the arch or horseshoe effect in other ordination methods (e.g. principal coordinate or correspondence analysis, Podani and Miklós 2002). NMDS has also been found to better explain overall distribution patterns in multidimensional palaeontological data sets (e.g. Clapham 2011).

All datasheets and scripts, using the $R$ working environment (R Development Core Team 2019), to produce the analyses and figures presented herein are available at GitHub (https://github.com/fossilrich/Kanosh.git).

\section{Results}

Faunal associations

The cluster analysis (Fig. 7) yielded three relatively wellresolved groups of taxa. They also show a clear distinction within the NMDS plot (Fig. S5). These are grouped into benthic associations. Figure 8 shows the taxonomic composition, the relative abundance, and the ecological guilds of observed species within each association. Association 1 includes eight species and is dominated by the brachiopods Shoshonorthis michaelis, Anomalorthis utahensis, and A. lonensis and thus 
Table 1 Taxa/groups recognised in this study. References do not necessarily refer to species' authors but to the most recent and accepted taxonomic treatments. Guilds refer to ecological categories from Bambach (1983) as applied in Bambach et al. (2007)

\begin{tabular}{|c|c|c|c|c|c|}
\hline \multirow[t]{2}{*}{ Species } & \multirow[t]{2}{*}{ Group } & \multicolumn{3}{|l|}{ Guilds } & \multirow[t]{2}{*}{ Reference } \\
\hline & & Tiering & Motility & Feeding & \\
\hline Shoshonorthis michaelis & Brachiopod & Surficial & Nonmotile, attached & Suspension & Jaanusson and Bassett (1993) \\
\hline Anomalorthis lonensis & Brachiopod & Surficial & Nonmotile, attached & Suspension & Ulrich and Cooper (1938) \\
\hline Anomalorthis utahensis & Brachiopod & Surficial & Nonmotile, attached & Suspension & Ulrich and Cooper (1938) \\
\hline Desmorthis nevadensis & Brachiopod & Surficial & Nonmotile, attached & Suspension & Ulrich and Cooper (1938) \\
\hline Hesperonomiella minor & Brachiopod & Surficial & Nonmotile, attached & Suspension & Ulrich and Cooper (1938) \\
\hline cf. Wahwahlingula sp. & Brachiopod & Shallow & Fac-motile, attached & Suspension & Popov et al. (2002) \\
\hline Murchisonia sp. & Gastropod & Surficial & Motile, slow & Grazer & Rohr (1996) \\
\hline Malayispira sp. & Gastropod & Surficial & Motile, slow & Grazer & Rohr (1994) \\
\hline Lophospira perangulata & Gastropod & Surficial & Motile, slow & Grazer & Rohr (1996) \\
\hline cf. Bathyurellus sp. & Trilobite & Surficial & Motile, fast & Surf. deposit & --- \\
\hline Pseudoolenoides ludificatus & Trilobite & Surficial & Motile, fast & Surf. deposit & Adrain et al. (2012) \\
\hline Pseudoolenoides dilectus & Trilobite & Surficial & Motile, fast & Surf. deposit & Adrain et al. (2012) \\
\hline Pseudoolenoides pogonipensis & Trilobite & Surficial & Motile, fast & Surf. deposit & Adrain et al. (2012) \\
\hline Pseudomera barrandei & Trilobite & Surficial & Motile, fast & Predator & Whittington (1961) \\
\hline Kanoshia sp. & Trilobite & Surficial & Motile, fast & Predator & --- \\
\hline Bathyurellus pogonipensis & Trilobite & Surficial & Motile, fast & Surf. deposit & Hintze (1953) \\
\hline Kanoshia kanoshensis & Trilobite & Surficial & Motile, fast & Predator & Hintze (1953) \\
\hline \multirow[t]{6}{*}{ Not further determined } & Receptaculitid & Surficial & Nonmotile, attached & Other & --- \\
\hline & Leperditicopid & Surficial & Motile, fast & Detritus & --- \\
\hline & Ostracods & Surficial & Motile, fast & Detritus & --- \\
\hline & Crinoids & Erect & Nonmotile, attached & Suspension & --- \\
\hline & Bryozoans & Surficial & Nonmotile, attached & Suspension & --- \\
\hline & Cephalopods & Pelagic & Motile, slow & Predator & --- \\
\hline
\end{tabular}

by stationary, epifaunal suspension feeders. The remaining species are trilobites, most notably Pseudomera barrandei and Kanoshia kanoshensis. Association 2 is quite similar but its third most abundant species is Desmorthis nevadensis instead of Anomalorthis lonensis which it lacks altogether. The only trilobite is Kanoshia kanoshensis. Diversity is also lower with five species present. Association 3 contains seven species and is dominated by Pseudoolenoides pogonipensis, Shoshonorthis michaelis, and Bathyurellus pogonipensis. All other species are too rare to make robust assumptions on their recurrent association with the other taxa. All these diversities appear relatively low (see the "Discussion" section). Rarefaction curves (Fig. S6) indicate that these diversities could not have been improved by additional collection effort. Only association 3 hints to be undersampled but it shows a similar trajectory to association 1 which contains only one more species.

\section{Distribution of associations}

The spatial and stratigraphic distribution of the three associations is shown in Fig. 3.
Association 3 is exclusively recorded in the lower part of the upper olive shale member of Section FMN, which represents the most distal facies of the formation. It is the only association which is dominated by the trilobites Pseudoolenoides pogonipensis and Bathyurellus pogonipensis which are absent (or extremely rare) in the two other associations. Besides the rarity of brachiopods, more "robust" trilobites such as Kanoshia kanoshensis or Pseudomera barrandei are absent here. Both suggest that this is in fact an environmental signal. The brachiopod-dominated associations 1 and 2 occur throughout the formation. Association 2 which shows the highest brachiopod dominance tends to occur in more calcareous and bioclastic units such as the calcisiltite member (Fig. 3). This suggests that the trilobite to brachiopod ratio more or less reflects a proximal-distal signal within the Kanosh Formation.

Associated faunal elements

Taxa or groups that have not been considered in the analysis for reasons outlined in the "Locality and methods" section but do occur abundantly in the Kanosh Formation are bryozoans, 

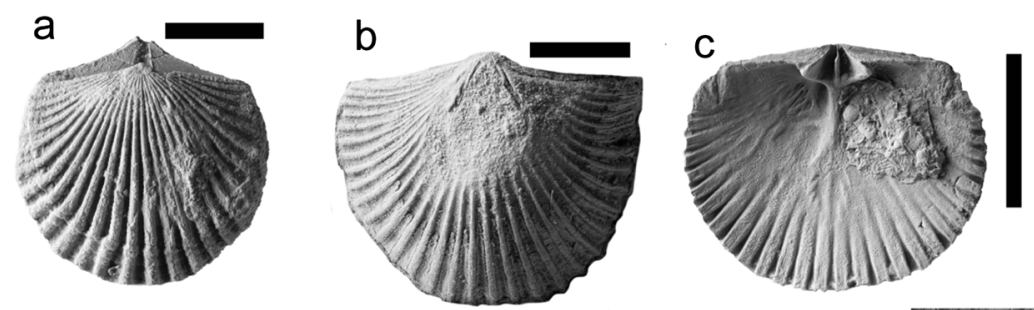

e
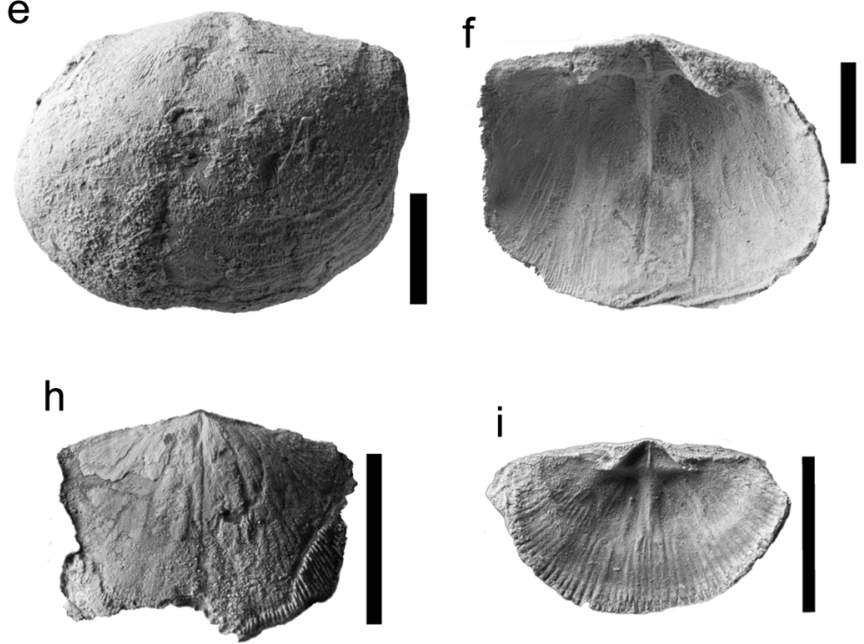

Fig. 4 Brachiopods recognised in the data set. a Shoshonorthis michaelis, external view dorsal valve, scale $=5 \mathrm{~mm}$, float around FMN-10, Kanosh Formation. b Shoshonorthis michaelis, external view ventral valve, scale $=5 \mathrm{~mm}$, FMS-7, Kanosh Formation. c Shoshonorthis michaelis, internal view dorsal valve, scale $=5 \mathrm{~mm}$, float around FMN-10, Kanosh Formation. d Shoshonorthis michaelis, external view dorsal valve, scale $=10 \mathrm{~mm}$, float around FMN-10, Kanosh Formation. e Anomalorthis utahensis, external view dorsal valve, scale $=5 \mathrm{~mm}$, float around FMN-10, Kanosh Formation. f Anomalorthis utahensis, internal
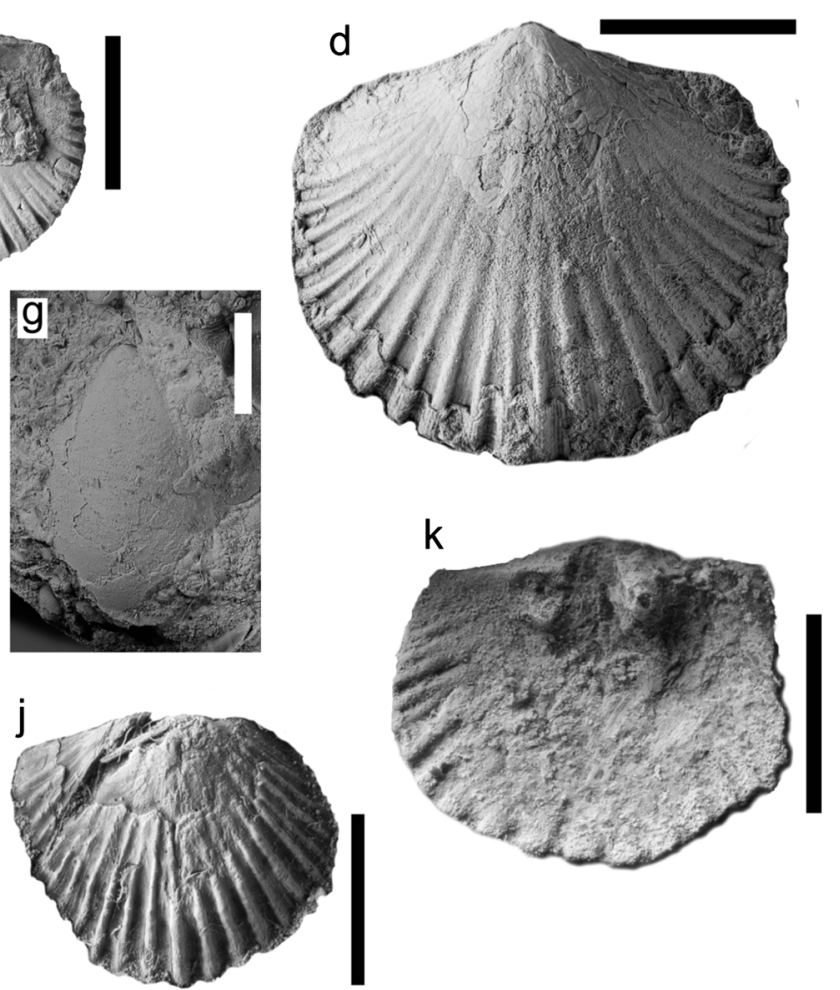

view dorsal valve, scale $=5 \mathrm{~mm}$, float around FMN-10, Kanosh Formation. $\mathbf{g}$ cf. Wahwahlingula sp., external view dorsal valve, scale $=$ $5 \mathrm{~mm}, \mathrm{FMN}-8$, Kanosh Formation. h Anomalorthis lonensis, external view dorsal valve, scale $=5 \mathrm{~mm}$, FMN -4 , Kanosh Formation. i Anomalorthis lonensis, internal view dorsal valve, scale $=5 \mathrm{~mm}$, FMN3, Kanosh Formation. j Desmorthis nevadensis, external view dorsal valve, scale $=5 \mathrm{~mm}$, CYP-9, Kanosh Formation. k Desmorthis nevadensis, internal view dorsal valve, scale $=5 \mathrm{~mm}$, CYP-10, Kanosh Formation ostracods, and echinoderms. Bioclastic grain and rudstones of an inner-shelf origin are mainly composed of indeterminable echinoderm debris and fragments of bryozoans (Fig. S4). Additionally, slabs of the same lithofacies feature eocrinoid holdfasts. The echinoderm fauna of the Kanosh Formation is considered understudied (Sumrall and Sprinkle 2015) but is estimated to contain more than ten genera (Sprinkle and Guensburg 1997). The rarity of articulated material has possibly aggravated reliable systematic identifications of taxa that are not easy to recognise (see Sumrall and Sprinkle (2015) for notable an exception). Hinds (1970) and Ernst et al. (2007) provided a taxonomic overview of bryozoan species recorded in the Kanosh Formation. Combined, these papers recognised nine species. Ostracods may be particularly diverse (Berdan 1988). Millimetre-sized "macrotonellids" (Hintze (1951) but see Berdan (1988)) occur throughout the formation. Respective monospecific centimetre-thick beds are observed in the fine-grained distal facies of the shale members. In particular, the calcisiltite member and the Lehman Formation contain monospecific assemblages of fairly large (several $\mathrm{mm}$ to $\mathrm{cm}$ ) leperditocopid arthropods (Vannier et al. 2001). These would almost certainly form an own association which is characteristically found in this part of the upper Pogonip Group. Their dominance most likely mirrors harsh environmental conditions in intertidal to supratidal carbonate environments. Gastropods may be observed throughout the Kanosh Formation but they do not occur in samples that we have recognised as (para-)autochthonous communities. However, murchisonids are especially common in restricted lagoonal facies of the calcisiltite member and the Lehman Formation. Larger fragments of orthocone nautiloid shells were abundantly found as float on shale intervals. Their stratigraphic distribution is hard to ascertain because of the patchy record. In summary, besides the noticeably impoverished in situ trilobite and brachiopod faunas that form the core of our analysis, several important clades of the "Palaeozoic Fauna" are reliable elements of the Kanosh Basin. They apparently flourished in shallow, wave-agitated skeletal carbonate bottoms, or, as in case of the orthocones, in the water column. 

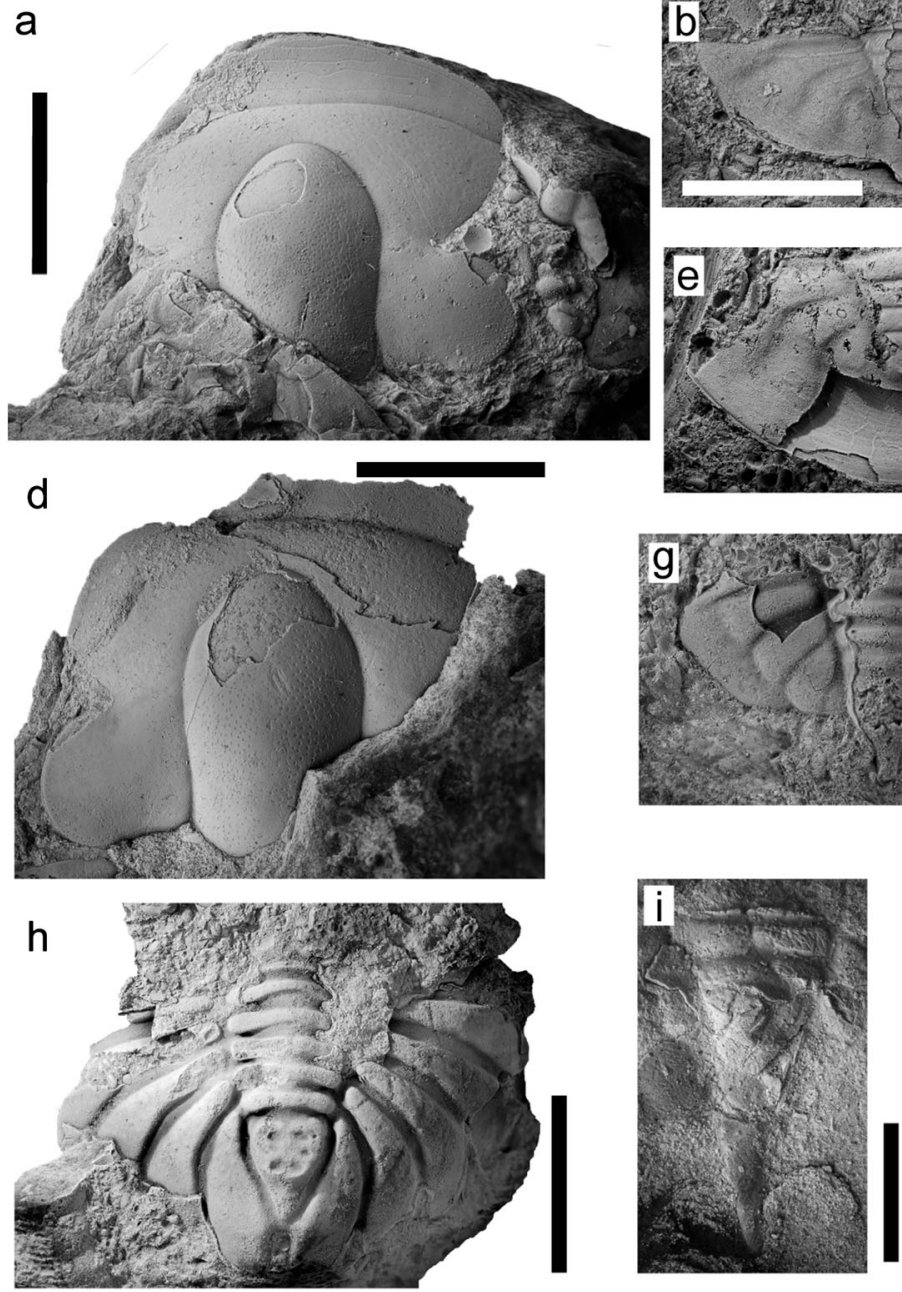
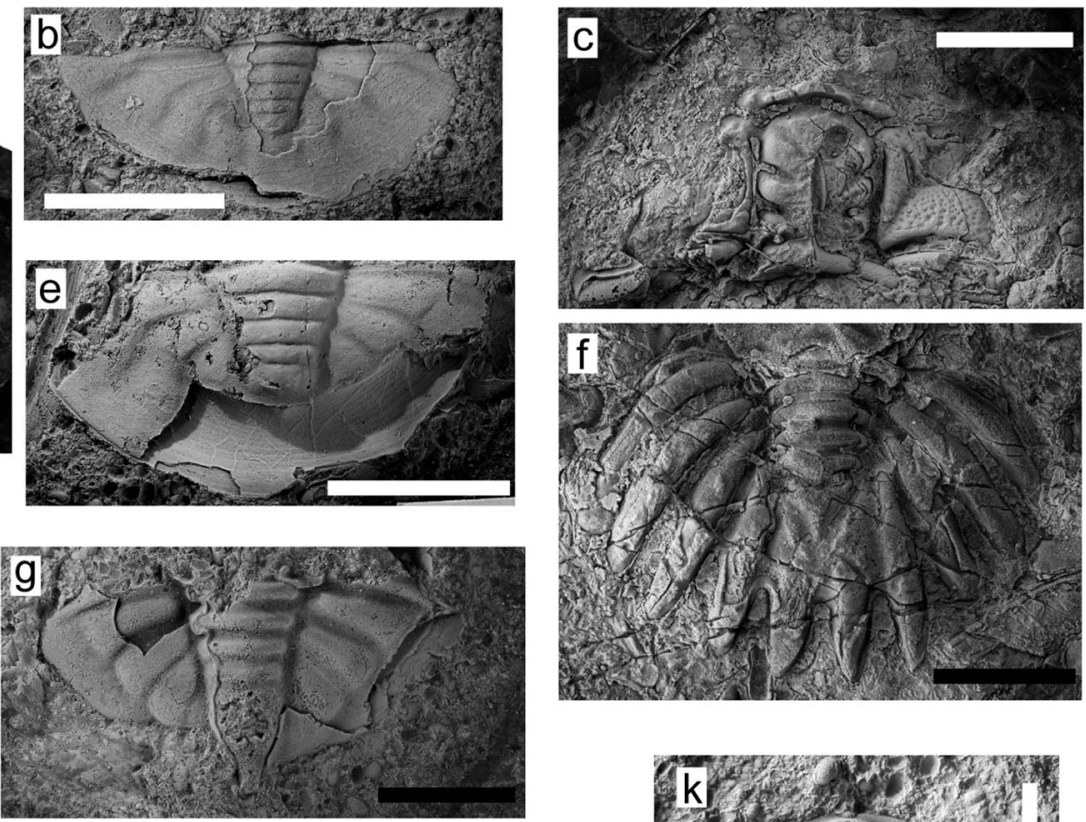

.

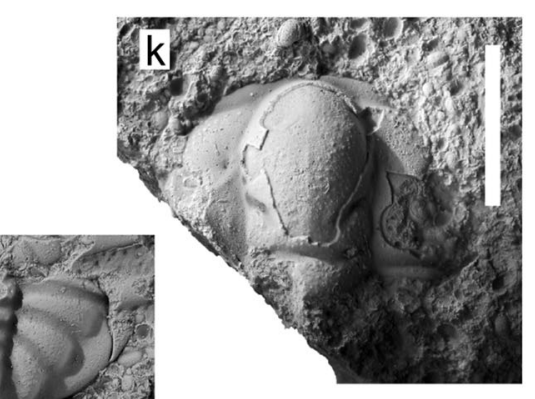

Fig. 5 Trilobites recognised in the data set. a Bathyurellus pogonipensis, cranidium, scale $=10 \mathrm{~mm}$, FMN-7, Kanosh Formation. b Bathyurellus pogonipensis, pygidium, scale $=10 \mathrm{~mm}, \mathrm{FMN}-9$, Kanosh Formation. $\mathbf{c}$ Kanoshia kanoshensis, cephalon, scale $=5 \mathrm{~mm}$, FMS-13, Kanosh Formation. d Bathyurellus pogonipensis, cranidium, scale $=10 \mathrm{~mm}$, FMN-7, Kanosh Formation. e Bathyurellus pogonipensis, pygidium, scale $=10 \mathrm{~mm}$, FMN-10, Kanosh Formation. f Kanoshia kanoshensis, pygidium, scale $=10 \mathrm{~mm}$, FMS-13, Kanosh Formation. g
Pseudoolenoides pogonipensis, pygidium, scale $=5 \mathrm{~mm}, \mathrm{FMN}-10$, Kanosh Formation. h Pseudomera cf. barrandei, pygidium, scale $=$ $10 \mathrm{~mm}$, FMS-13, Kanosh Formation. i Pseudoolenoides ludificatus pygidium, scale $=5 \mathrm{~mm}$, FMS -10 , Kanosh Formation. j Pseudoolenoides pogonipensis, pygidium, scale $=5 \mathrm{~mm}, \mathrm{FMN}-10$, Kanosh Formation. k Pseudoolenoides dilectus, cranidium, scale = $5 \mathrm{~mm}$, FMS-10, Kanosh Formation

occurrences such as the Paleobiology Database. This provides a better comparability to our data. This diversity would hardly be reached, even if one would include species of the associated faunal elements reported above. Based on own experience, decidedly low-diverse benthic communities observed in the immediate aftermath of the end-Permian mass extinction (Hofmann et al. 2013; Hofmann et al. 2015) do exhibit similar species richness values between five and ten species.

Abiotic controls

The limited diversity observed might be central to the understanding of spatial and temporal patterns of the 


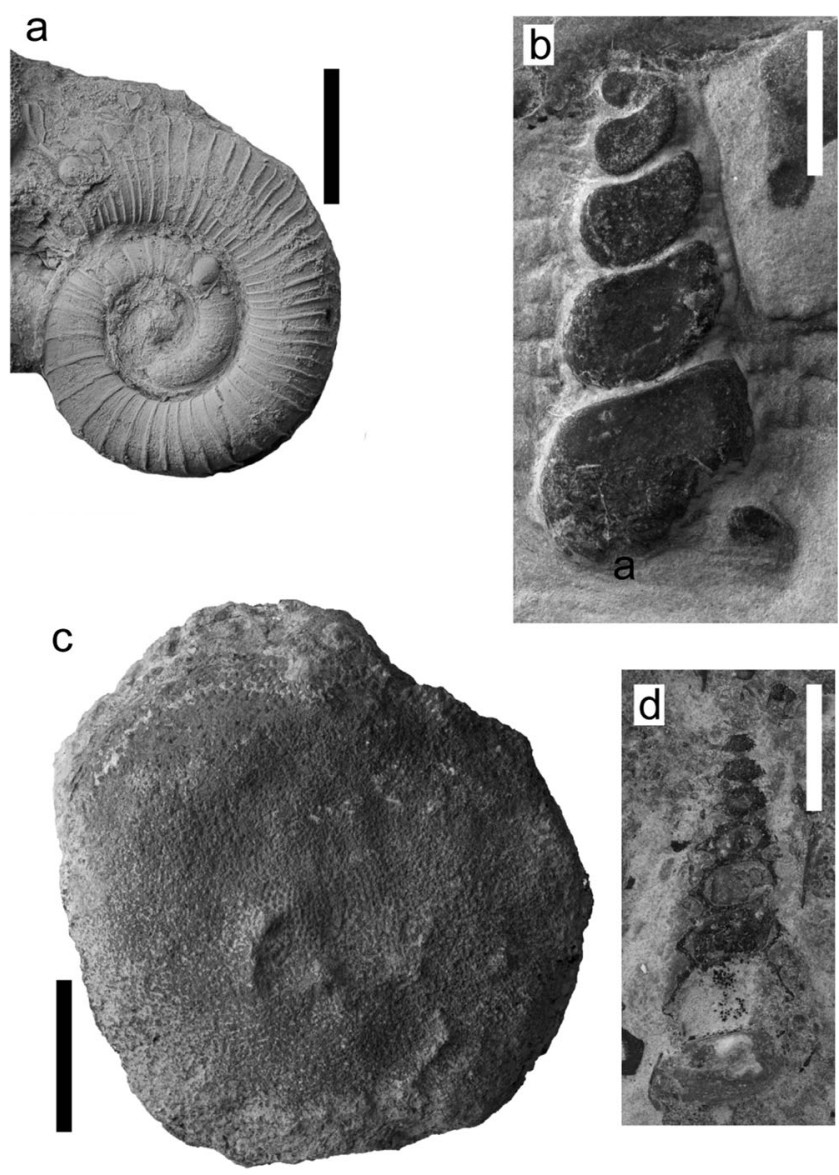

Fig. 6 Gastropods and problematica recognised in the data set. a Malayispira sp., apical view, scale $=10 \mathrm{~mm}$, CYP-9, Kanosh Formation. b Murchisonia sp., pygidium, lateral view, scale $=5 \mathrm{~mm}$, FMN-26, Lehman Formation. c Receptaculitid, scale $=20 \mathrm{~mm}$, FMN-4, Kanosh Formation. d Lophospira perangulata, cross-sectional view on weathered slab, scale $=5 \mathrm{~mm}$, FMN-25, Lehman Formation

GOBE. First of all, the Kanosh Formation represents a somewhat restricted basin with a considerable influx of fine siliclastic detritus, which usually imparts physical stress especially on immobile filter feeding organisms (Algeo and Twitchett 2010). This alone could readily explain the paucity on resident brachiopod communities. Other stress factors such as high sea surface temperatures (Trotter et al. 2008) or low atmospheric oxygen (Edwards et al. 2017) have been proposed to stall diversification of marine clades during the first half of the Ordovician. Rasmussen et al. (2019) show that the main diversification phase during the mid-Darriwilian coincides with sea surface temperatures reaching modern-day equatorial values (Trotter et al. 2008) as well as notably rising oxygen levels (Edwards et al. 2017) and improved oceanic circulation (Rasmussen et al. 2016). With an age of Dapingian to earliest Darriwilian, the Kanosh Formation just precedes this interval. Brachiopod faunas and respective range- through-diversities observed in the Simpson Group of the American mid-continent (Trubovitz and Stigall 2016) showed a steady rise from less than ten species recorded in the late Dapingian to more than 35 in the mid-Darriwilian. Although more volatile because of numerous stratigraphic gaps and condensed facies, the record from Baltica (Rasmussen et al. 2007) essentially shows the same pattern. In a series of recent database analyses (e.g. Kröger et al. (2019) and Rasmussen et al. (2019)) and thorough review of available data and literature (Stigall et al. 2019), it has now become apparent that the GOBE main phase occurs during the Darriwilian stage. If the timing of the diversification holds true for the western part of Laurentia as well, the Kanosh Formation still records a "baseline" fauna of the Pre-GOBE phase (sensu Stigall et al. (2019)) being characterised by a low community species richness.

Saltzman et al. (2015) provided evidence from the same basin that elevated extinction rates of the Early Palaeozoic relate to recurrent anoxia and elevated temperatures during the Cambrian and Early Ordovician. In fact, corresponding strata in the Pogonip Group (the House Formation and the lower part of the Fillmore Formation) do exhibit exceedingly low diversities in the benthic macrofauna (own observations, but see Hintze and Davies (2003) for general overview). The herein observed comparatively low diversity of the much younger Kanosh Fauna suggests that local ecological effects may exert primary control on diversity patterns.

\section{Biotic controls}

However, why is there a lag phase between the definite establishment of a Palaeozoic-type level bottom fauna and intraclade diversification? The general impression that most typical clades of the Palaeozoic fauna are present in the Kanosh System underscores the hypothesis that environmental stress is not the sole driver behind the observed diversity patterns. On a larger macroecological scale, there may be also biotic factors that could explain this relatively low diversity. Kröger et al. (2019) demonstrated that increased genus longevity precedes and accompanies the main phase of diversification during the GOBE. Besides one possible explanation that recurrent anoxia and elevated temperatures (Saltzman et al. 2015) were the cause for elevated extinction rates earlier, Kröger et al. (2019) posit that evolutionary dynamics (i.e. the mode of diversity accumulation) changed fundamentally in the course of the GOBE. One main reason is that genus longevity even increases throughout intervals with elevated extinction rates during the Late Ordovician (e.g. the Katian and the Late Ordovician mass extinction). Kröger et al. (2019) interpret this pattern to reflect generally higher ecosystem resilience towards changing environmental conditions. The 
Fig. 7 Results of unweighted paired-group cluster analysis using Raup's similarity index. Numbers refer to benthic associations portrayed in the text

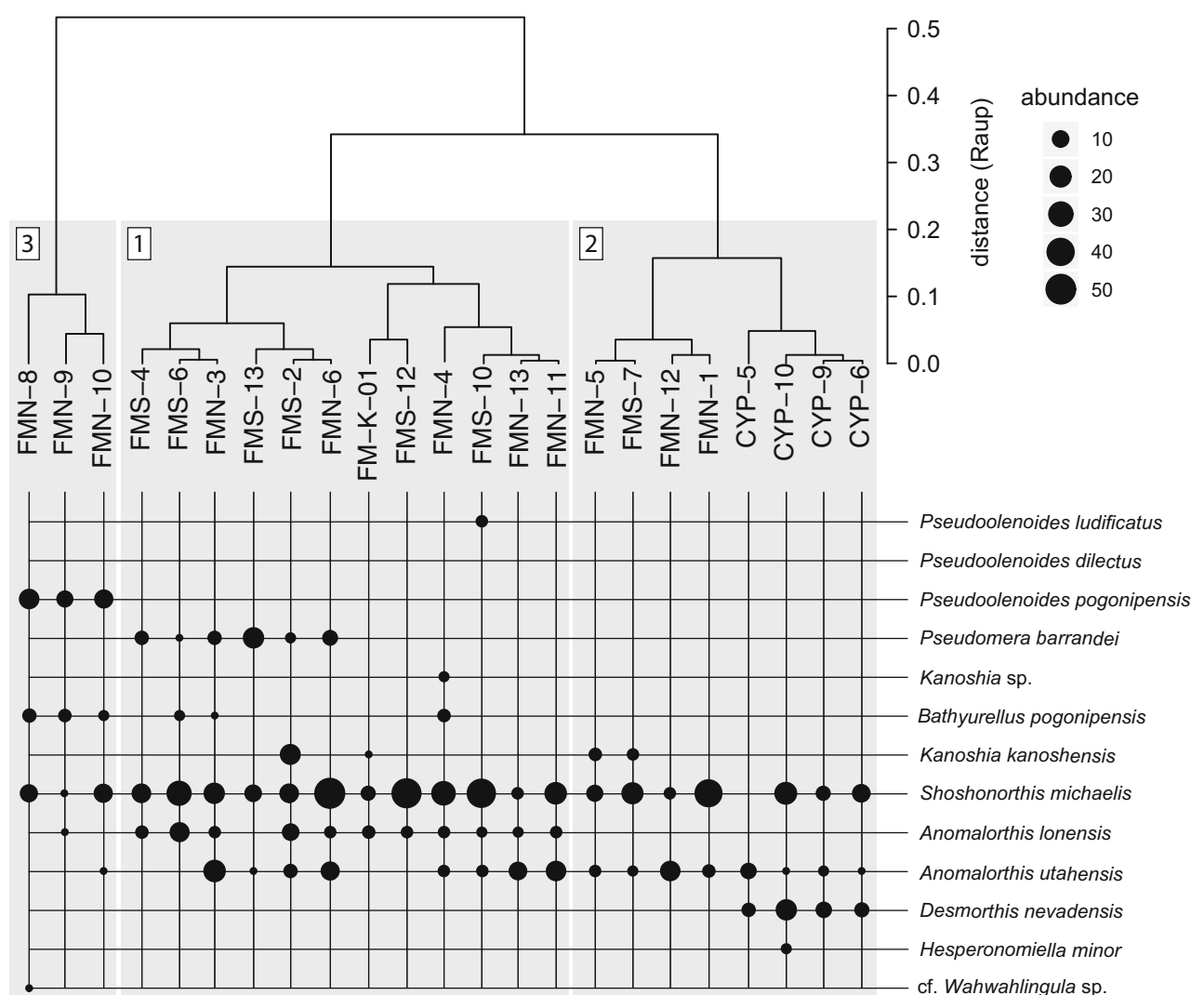

ability to buffer against environ-mental disruption probably stems from enhanced ecological complexity involving the establishment of stable pelagic food chain (Servais et al. 2008; Servais et al. 2010), predation (Huntley and Kowalewski 2007), reef ecosystems (Webby 2002), expanding bioturbation (Buatois et al. 2016; Tarhan 2018), and appearance of skeletal hardgrounds (Wilson et al. 1992). Palaeoecological modelling has shown that strongly intertwined biotic networks are much more resilient towards stress factors (Roopnarine and Angielczyk 2015), concomitantly allowing species accumulation. The Darriwilian breakthrough of diversification rates may result from the increasingly intertwined ecological connections, something that is not yet fully established by Kanosh times.

Additional biotic factors that might control sudden changes in the mode of diversity accumulation are positive species interactions such as predation and competition. Hautmann (2014) and Hofmann et al. (2019) use different trajectories of alpha and beta diversity to infer to what extent competition fosters environmental partitioning and, thus, drives bulk diversity of neighbouring habitats. Our data allow for assessing alpha diversity but also beta diversity, despite only on descriptive terms before data from other communities of the Pogonip become available for comparison. Even in incomplete data sets, beta diversity is reliably captured by the most abundant taxa (Roden et al. 2018). All brachiopod species recorded herein do occur in all observed subhabitats of the upper Pogonip (Fig. 9), including quiet water conditions, shallower wave-agitated carbonate shoals, as well as intertidal carbonate lagoons. This could indicate that brachiopod faunas have not yet reached the habitat contraction phase (Hautmann 2014), which is characterised by rising beta diversity, expressing environmental partitioning induced by competition. The somewhat more pronounced habitat preferences of trilobites in the Kanosh system (see the "Results" section) may signal that these mobile predators and deposit feeders enter competitive regimes at a lower species richness. This is predicted by Hautmann's (2014) model if one accounts for differing - in this case higherintrinsic rates of competition possibly depending on cladespecific metabolic rates (Hautmann et al. 2015). If the net energy utilised by a group of organisms is higher (here trilobites opposed to brachiopods), the same group will be earlier confronted by resource limits, and hence competition.

\section{Outlook}

To test if this model could satisfactorily explain the somehow sudden diversification of clades during the GOBE on a local scale, further comparative analyses 
Fig. 8 Abundance distribution and trophic guilds in each benthic association

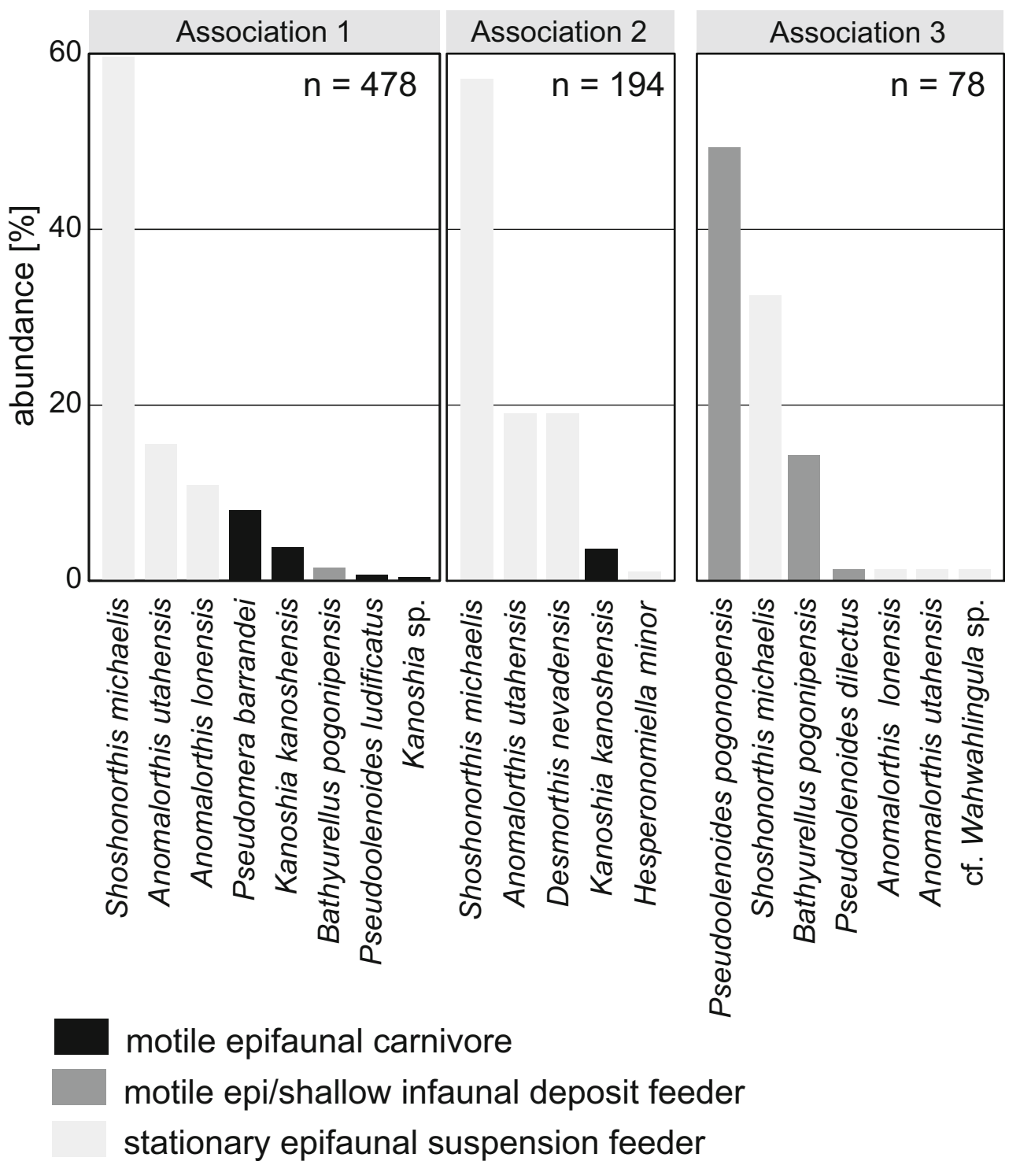

of preceding and succeeding ecosystems with respect to the Kanosh Formation are required. What is especially needed is a baseline for beta diversity to assess the rate of habitat partitioning of the Kanosh system. In any case, the Kanosh Formation most likely records a transitional fauna between the "Pre-GOBE" and the "Main GOBE phase" (Stigall et al. 2019). Furthermore, it will be crucial to understand that what extent the Pogonip faunas do represent in situ speciations or phases of migration of older taxa. The diversity pattern tentatively implies that the macroecological regime resides in a low competitive stage (Hautmann 2014; Hofmann et al. 2019) and a mode of species accumulation that is typically for earlier Palaeozoic ecosystems (Kröger et al. 2019).

\section{Conclusions}

Multivariate analyses of faunal assemblages of the Kanosh Formation show that benthic communities exhibited rather low diversity both in terms of habitat and in-between habitat diversity. This results probably from the restricted nature of depositional system manifested in this unit. However, the principle presence of all major marine clades and ecotypes of a mature mid-Palaeozoic shallow marine ecosystem strongly suggests that abiotic stress factors may not be the only explanation. In accordance with most recent findings, we suggest that the macroecological regime more resembles that of the Cambrian, which could be characterised by low speciation rates, low rates of competition, and low ecosystem resilience. We furthermore conclude that the taxonomic diversification 


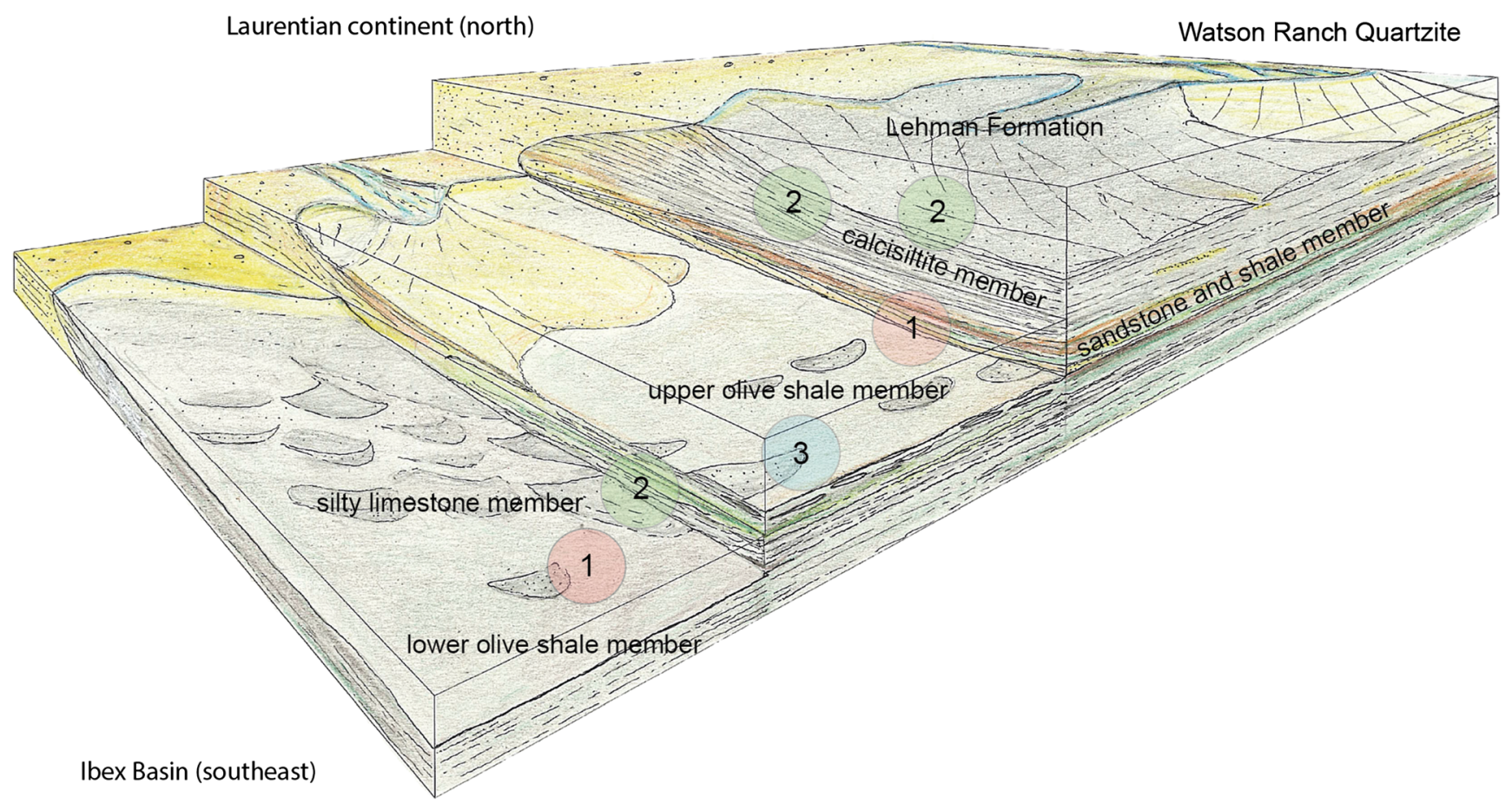

Fig. 9 Composite model of the Kanosh/Lehman depositional system showing the spatial and stratigraphic distribution of the benthic association. Cardinal directions refer to modern-day geography (compare to Fig. 2b)

clearly postdates the establishment of marine macroinvertebrate clades and respective ecological guilds.

Acknowledgements We are indebted to Kevin Bylund (Spanish Fork, UT, $\mathrm{http} / /$ www.ammonoid.com) for intrepid field guidance. Samples have been collected under the permit UT19-014S issued by Bureau of Land Management (BLM). The support of H. Gregory McDonald (BLM State Palaeontologist, Salt Lake City) is greatly acknowledged. Jim and Ruby Jenks (West Jordan, UT) are thanked for logistic support and hospitality during the field season. The Ibex area is located on US public land under the stewardship of the BLM of the US Department of the Interior; access to this land is gratefully acknowledged. The manuscript benefited greatly from comments by Ben Dattilo (Purdue University) and an anonymous reviewer.

Funding information Open Access funding provided by Projekt DEAL. This study has been financially supported by the Deutsche Forschungsgemeinschaft, DFG Grant HO 5624/2-1 (to R.H.). It is a contribution to the IGCP 553 Program: Onset of the Great Ordovician Biodiversification Event.

\section{Compliance with ethical standards}

Conflict of interest The authors declare that they have no conflict of interests.

Open Access This article is licensed under a Creative Commons Attribution 4.0 International License, which permits use, sharing, adaptation, distribution and reproduction in any medium or format, as long as you give appropriate credit to the original author(s) and the source, provide a link to the Creative Commons licence, and indicate if changes were made. The images or other third party material in this article are included in the article's Creative Commons licence, unless indicated otherwise in a credit line to the material. If material is not included in the article's Creative Commons licence and your intended use is not permitted by statutory regulation or exceeds the permitted use, you will need to obtain permission directly from the copyright holder. To view a copy of this licence, visit http://creativecommons.org/licenses/by/4.0/.

\section{References}

Adrain, J. M., McAdams, N. E. B., \& Karim, T. S. (2012). The Middle Ordovician bathyurid trilobite Pseudoolenoides, with a revised trilobite biostratigraphy of the Dapingian and lower Darriwilian of western Laurentia. Zootaxa, 3467, 1-97.

Algeo, T. J., \& Twitchett, R. J. (2010). Anomalous Early Triassic sedimentfluxes due to elevated weathering rates and their biological consequences. Geology, 38, 1023-1026.

Bambach, R. K. (1983). Ecospace utilization and guilds in marine communities through the Phanerozoic. In M. J. S. Tevesz \& P. L. McCallm (Eds.) Biotic interactions in recent and fossil benthic communities (pp. 719-746). Boston: Springer US.

Bambach, R. K., Bush, A. M., \& Erwin, D. H. (2007). Autecology and the filling of ecospace: key metazoan radiations. Palaeontology, 50, 1-22.

Berdan, J. M. (1988). Middle Ordovician leperditicopid ostracods from the Ibex area, Millard County, western Utah. In D. L. Wolberg (Ed.) Contributions to Paleozoic paleontology and stratigraphy in honor of Rousseau H. Flower (pp. 273-301). Socorro: New Mexico Bureau of Mines and Mineral Resources memoir.

Blakey, R. C. (2019). Deep time maps. https://deeptimemaps.com/

Boyer, D. L., \& Droser, M. L. (2003). Shell beds of the Kanosh and Lehman Formations of Western Utah: paleoecolgocial and paleoenvironmental interpretations. Brigham Young University Geology Studies, 47, 1-16. 
Buatois, L. A., Mángano, M. G., Olea, R. A., \& Wilson, M. A. (2016). Decoupled evolution of soft and hard substrate communities during the Cambrian Explosion and Great Ordovician Biodiversification Event. Proceedings of the National Academy of Sciences of the United States of America, 113(25), 6945-6948.

Clapham, M. E. (2011). Ordination methods and the evaluation of Ediacaran communities. In M. Laflamme, J. D. Schiffbauer, \& S. Q. Dornbos (Eds.) Quantifying the evolution of early life, Topics in Geobiology (Vol. 36, pp. 3-21).

Colmenar, J., \& Rasmussen, C. M. O. (2018). A Gondwanan perspective on the Ordovician radiation constrains its temporal duration and suggests first wave of speciation, fuelled by Cambrian clades. Lethaia, 51(2), 286-295.

Dattilo, B. F. (1993). The Lower Ordovician Fillmore Formation of western Utah: storm-dominated sedimentation on a passive margin. Brigham Young University Geology Studies, 39, 71-100.

Edwards, C. T., \& Saltzman, M. R. (2014). Carbon isotope (delta C-13(carb)) stratigraphy of the Lower-Middle Ordovician (Tremadocian-Darriwilian) in the Great Basin, western United States: implications for global correlation. Palaeogeography, Palaeoclimatololgy, Palaeoecology, 399, 1-20.

Edwards, C. T., Saltzman, M. R., Royer, D. L., \& Fike, D. A. (2017). Oxygenation as a driver of the Great Ordovician Biodiversification Event. Nature Geoscience, 10(12), 925-931.

Ernst, A., Taylor, P. D., \& Wilson, M. A. (2007). Ordovician bryozoans from the Kanosh Formation (Whiterockian) of Utah, USA. Journal of Paleontology, 81(5), 998-1008.

Finnegan, S., \& Droser, M. L. (2005). Relative and absolute abundance of trilobites and rhynchonelliform brachiopods across the Lower/ Middle Ordovician boundary, eastern Basin and Range. Paleobiology, 31(3), 480-502.

Fortey, R. A., \& Droser, M. L. (1996). Trilobites at the base of the Middle Ordovician, western United States. Journal of Paleontology, 70(1), 71-97.

Foster, W. J., Danise, S., Price, G. D., \& Twitchett, R. J. (2017). Subsequent biotic crises delayed marine recovery following the late Permian mass extinction event in northern Italy. PLoS One, 12(3).

Franeck, F., \& Liow, L. H. (2019). Dissecting the paleocontinental and paleoenvironmental dynamics of the great Ordovician biodiversification. Paleobiology, 45(2), 221-234.

Fürsich, F. T., Freytag, S., Rohl, J., \& Schmid, A. (1995). Paleoecology of benthic associations in salinity-controlled marginal marine environments - examples from the Lower Bathonian (Jurassic) of the Causses (Southern France). Palaeogeography, Palaeoclimatololgy, Palaeoecology, 113(2-4), 135-172.

Gilinsky, N. L., \& Bennington, J. B. (1994). Estimating numbers of whole individuals from collections of body parts, a taphonomic limitation of the paleontological record. Paleobiology, 202(2), 245-258.

Harper, D. A. T., Zhan, R. B., \& Jin, J. S. (2015). The Great Ordovician Biodiversification Event, reviewing two decades of research on diversity's big bang illustrated by mainly brachiopod data. Palaeoworld, 24(1-2), 75-85.

Hautmann, M. (2014). Diversification and diversity partitioning. Paleobiology, 40(2), 162-176.

Hautmann, M., Bagherpour, B., Brosse, M., Frisk, A., Hofmann, R., Baud, A., Nützel, A., Goudemand, N., \& Bucher, H. (2015). Competition in slow motion, the unusual case of benthic marine communities in the wake of the end-Permian mass extinction. Palaeontology, 58(5), 871-901.

Hinds, R. W. (1970). Ordovician Bryozoa from the Pogonip Group of Millard County, western Utah. Brigham Young University Geology Studies, 17, 19-40

Hintze, L. F. (1951). Lower Ordovician detailed stratigraphic sections for western Utah. Utah Geological and Mineralogical Survey Bulletin, $39,1-99$.
Hintze, L. F. (1953). Lower Ordovician trilobites from western Utah and eastern Nevada. Utah Geological and Mineralogical Survey Bulletin, 48, 1-249.

Hintze, L. F. (1973). Lower and Middle Ordovician stratigraphic sections in the Ibex area, Millard County, Utah. Brigham Young University Geology Studies, 20, 3-36.

Hintze, L. F, \& Davis, F. D. (2003). Geology of Millard County, Utah. Utah Geological Survey Bulletin 133, Salt Lake City, Utah, 305 pp.

Hofmann, R., Hautmann, M., \& Bucher, H. (2013). A new paleoecological look at the Dinwoody Formation (Lower Triassic, Western USA), intrinsic versus extrinsic controls on ecosystem recovery after the End-Permian mass extinction. Journal of Paleontology, 87(5), 854-880.

Hofmann, R., Hautmann, M., \& Bucher, H. (2015). Recovery dynamics of benthic marine communities from the Lower Triassic Werfen Formation, northern Italy. Lethaia, 48(4), 474-496.

Hofmann, R., Tietje, M., \& Aberhan, M. (2019). Diversity partitioning in Phanerozoic benthic marine communities. Proceedings of the National Academy of Sciences of the United States of America, 116(1), 79-83.

Huntley, J. W., \& Kowalewski, M. (2007). Strong coupling of predation intensity and diversity in the Phanerozoic fossil record. Proceedings of the National Academy of Sciences of the United States of America, 104(38), 15006-15010.

Jensen, R. G. (1967). Ordovician brachiopods from the Pogonip Group of Millard County. Brigham Young University Geology Studies, 14, 67-101.

Kröger, B., Franeck, F., \& Rasmussen, C. М. Ø. (2019). The evolutionary dynamics of the early Palaeozoic marine biodiversity accumulation. Proceedings of the Royal Society B, Biological Sciences, 286(1909), 1634-1641.

Li, X., \& Droser, M. L. (1999). Lower and Middle Ordovician shell beds from the basin and range province of the western United States (California, Nevada, and Utah). Palaios, 14(3), 215-233.

Miller, J. F., Evans, K. R., \& Dattilo, B. F. (2012). The great American carbonate bank in the miogeocline of western central Utah, tectonic influences on sedimentation. In, J. R Derby, R. D. Fritz, S. A. Longacre, W. A. Morgan, \& C. A. Sternbach (Eds.) The great American carbonate bank, the geology and economic resources of the Cambrian - Ordovician Sauk megasequence of Laurentia. American Association of Petroleum Geologists Memoir 98, 769854.

Myrow, P. M., Taylor, J. F., Miller, J. F., Ethington, R. L., Ripperdan, R. L., \& Allen, J. (2003). Fallen arches, dispelling myths concerning Cambrian and Ordovician paleogeography of the Rocky Mountain Region. Geological Society of America Bulletin, 155(6), 695-713.

Oksanen, J., Blanchet, F. G., Friendly, M., Kindt, R., Legendre, P., McGlinn, D., Peter, R., Minchin, O'Hara, R. B., Simpson, G. L., Solymos, P., Stevens, M. H. H., Szoecs, E., \& Wagner, H. (2019). Vegan: community ecology package. $R$ package version $2.5-5$. https, //CRAN.R-project.org/package=vegan

Podani, J., \& Miklós, I. (2002). Resemblance coefficients and the horseshoe effect in principal coordinates analysis. Ecology., 83, 33313343.

Popov, L. E., Holmer, L. E., \& Miller, J. F. (2002). Lingulate brachiopods from the Cambrian-Ordovician boundary beds of Utah. Journal of Paleontology, 76(2), 211-228.

R Development Core Team. (2019). $R$, a language and environment for statistical computing. Vienna: R Foundation for Statistical Computing.

Rasmussen, C. M. Ø., Hansen, J., \& Harper, D. A. T. (2007). Baltica, a mid Ordovician diversity hotspot. Historical Biology, 19(3), 255261.

Rasmussen, C. M. Ø., Ullmann, C. V., Jakobsen, K. G., Lindskog, A., Hansen, J., Hansen, T., Eriksson, M. E., Dronov, A., Frei, R., Korte, C., Nielsen, A. T., \& Harper, D. A. T. (2016). Onset of main 
Phanerozoic marine radiation sparked by emerging Mid Ordovician icehouse. Scientific Reports, 6.

Rasmussen, C. M. Ø., Kröger, B., Nielsen, M. L., \& Colmenar, J. (2019). Cascading trend of Early Paleozoic marine radiations paused by Late Ordovician extinctions. Proceedings of the National Academy of Sciences of the United States of America, 116(15), 7207-7213.

Roden, V., Kocsis, Á., Zuschin, M., \& Kießling, W. (2018). Reliable estimates of beta diversity with incomplete sampling. Ecology, 99(5), 1051-1062.

Rohr, D. M. (1994). Ordovician (Whiterockian) gastropods of Nevada, Bellerophontoidea Macluritoidea and Euomphaloidea. Journal of Paleontology, 68(3), 473-486.

Rohr, D. M. (1996). Ordovician (Whiterockian) gastropods of Nevada part 2. Journal of Paleontology, 70(1), 54-61.

Roopnarine, P. D., \& Angielczyk, K. D. (2015). Community stability and selective extinction during the Permian-Triassic mass extinction. Science, 350(6256), 90-93.

Ross, R. J. (1970). Ordovician brachiopods trilobites and stratigraphy in eastern and central Nevada. Geological Survey professional paper, 639, 1-99.

Ross, R. J., James, N. P., Hintze, L. F., \& Poole, F. G. (1989). Architecture and evolution of a Whiterockian (early Middle Ordovician) carbonate platform basin ranges of Western USA. In P. D. Crevello, J. L. Wilson, J. F. Sarg., \& J. R. Reed (Eds.) Controls on carbonate platform and basin development. Society of Economic Paleontologists and Mineralogists, 167-185.

Saltzman, M. R., Edwards, C. T., Adrain, J. M., \& Westrop, S. R. (2015). Persistent oceanic anoxia and elevated extinction rates separate the Cambrian and Ordovician radiations. Geology, 43(9), 807-810.

Sepkoski, J. J., Jr. (1981). A factor analytic description of the Phanerozoic marine fossil record. Paleobiology, 7(1), 36-53.

Sepkoski, J. J., Jr. (1988). Alpha beta or gamma, where does all the diversity go? Paleobiology, 14(3), 221-234.

Servais, T., Lehnert, O., Li, J., Mullins, G. L., Munnecke, A., Nützel, A., \& Vecoli, M. (2008). The Ordovician biodiversification, revolution in the oceanic trophic chain. Lethaia, 41(2), 99-109.

Servais, T., Owen, A. W., Harper, D. A. T., Kröger, B., \& Munnecke, A. (2010). The Great Ordovician Biodiversification Event (GOBE), the palaeoecological dimension. Palaeogeography, Palaeoclimatology, Palaeoecology, 294(3-4), 99-119.

Sprinkle, J., \& Guensburg, T. E. (1997). Appendix D4. Echinoderm biostratigraphy. In R. J. Jr Ross, L. F Hintze, R. L. Ethington, J. F. Miller, M. E Taylor, \& J. E. Repetski (Eds.) The Ibexian, lowermost series in the NorthAmerican Ordovician. U.S. Geological Survey Professional Paper 1579, 49-50.
Stigall, A. L., Edwards, C. T., Freeman, R. L., \& Rasmussen, C. M. Ø. (2019). Coordinated biotic and abiotic change during the Great Ordovician Biodiversification Event, Darriwilian assembly of early Paleozoic building blocks. Palaeogeography, Palaeoclimatololgy, Palaeoecology, 530, 249-270.

Sumrall, C. D., \& Sprinkle, J. (2015). Unusual ambulacral branching pattern in a new Ordovician giantedrioasteroid, Bizarroglobus. Journal of Paleontology, 89(2), 353-359.

Tarhan, L. G. (2018). The early Paleozoic development of bioturbationevolutionary and geobiological consequences.. Earth-Science Reviews 178, 177-207.

Trotter, J. A., Williams, I. S., Barnes, C. R., Lecuyer, C., \& Nicoll, R. S. (2008). Did cooling oceans trigger Ordovician biodiversification? Evidence from conodont thermometry. Science, 321(5888), 550 554.

Trubovitz, S., \& Stigall, A. L. (2016). Synchronous diversification of Laurentian and Baltic rhynchonelliform brachiopods, implications for regional versus global triggers of the Great Ordovician Biodiversification Event. Geology, 44(9), 743-746.

Ulrich, E. O., \& Cooper, G. A. (1938). Ozarkian and Canadian Brachiopoda. Geological Society Special papers, 13, 323.

Vannier, J., Wang, S., \& Coen, M. (2001). Leperditicopid arthropods (Ordovician-Late Devonian): functional morphology and ecological range. Journal of Paleontology, 75(1), 75-95.

Vecoli, M., Beck, J. H., \& Strother, P. K. (2015). Palynology of the Ordovician Kanosh Shale at Fossil Mountain Utah. Journal of Paleontology, 89(3), 424-447.

Webby, B. D. (2002). Patterns in Ordovician reef development. In W. Kiessling, E. Flügel, \& J. Golonka (Eds.) Phanerozoic reef patterns. SEPM Special Publication. SEPM Society for Sedimentary Geology Tulsa, 124-146.

Westrop, S. R., \& Adrain, J. M. (1998). Trilobite alpha diversity and the reorganization of Ordovician benthic marine communities. Paleobiology, 24(1), 1-16.

Whittington, H. B. (1961). Middle Ordovician Pliomeridae (Trilobita) from Nevada New York Quebec Newfoundland. Journal of Paleontology, 35(5), 911-922.

Wilson, M. A., Palmer, T. J., Guensburg, T. E., Finton, C. D., \& Kaufman, L. E. (1992). The development of an Early Ordovician hard ground community in response to rapid sea-floor calcite precipitation. Lethaia, 25(1), 19-34.

Publisher's note Springer Nature remains neutral with regard to jurisdictional claims in published maps and institutional affiliations. 